\title{
A STABLE DILUENT FOR PUREX PROCESS EXTRACTANTS
}

\author{
by \\ Henry Pollock \\ Separations Chemistry Division \\ June 1958
}

E. I. du Pont de Nemours \& Co. Explosives Department - Atomic Energy Division Technical Division - Savannah River Laboratory

Printed for

The United States Atomic Energy Commission Contract AT $(07-2)-1$ 


\section{DISCLAIMER}

This report was prepared as an account of work sponsored by an agency of the United States Government. Neither the United States Government nor any agency Thereof, nor any of their employees, makes any warranty, express or implied, or assumes any legal liability or responsibility for the accuracy, completeness, or usefulness of any information, apparatus, product, or process disclosed, or represents that its use would not infringe privately owned rights. Reference herein to any specific commercial product, process, or service by trade name, trademark, manufacturer, or otherwise does not necessarily constitute or imply its endorsement, recommendation, or favoring by the United States Government or any agency thereof. The views and opinions of authors expressed herein do not necessarily state or reflect those of the United States Government or any agency thereof. 


\section{DISCLAIMER}

Portions of this document may be illegible in electronic image products. Images are produced from the best available original document. 


\section{ABSTRACT}

The chemical stability and physical properties of n-dodecane make it a superior diluent for extractants such as are used in the Purex process. The chemical stability of commercial n-dodecane can be increased by purification with synthetic zeolites (molecular sieves). 


\section{CONTENTS}

\section{Page}

INTRODUCTION

SUMMARY

DISCUSSION

Source of Zirconium Ligands

Chemical Stability of Avaliable Diluents

Purification of n-Parafiins by Treatment with Molecular Sieves

\section{IIST OF TABLES}

Table

I Formation of Zirconium Ligands in Solvent Components and Solvents

II Chemical Stability and Physical Properties of Commercial Diluents

III Effect of Treatment of Commercial n-Dodecane with Molecular Sieves 


\section{A STABLE DILUENT FOR PUREX PROCESS EXTRACTANTS}

\section{INTRODUCTION}

Solvent extraction processes of the Purex type employ solvents that are solutions of tri-n-butyl phosphate (TBP) in hydrocarbon diluents. The purpose of the diluent is to reduce the density and viscosity of the extractant and to improve the separation characteristics of mixtures of the solvent with dilute nitric acid.

Purex solvent degrades when used for long periods of time and forms ligands which complex zirconium. (1) These ligands are not removed by normal washing: upon repeated use of the solvent they can accumulate to a point where their slow release of that part of the zirconium for which they have affinity will limit the purity of the Purex products. The ligand formation is due to degradation of the "purifled kerosene" diluent ("Ultrasene") when contacted with dilute nitric-nitrous acid solutions.

The purpose of this study was to find a hydrocarbon diluent that would demonstrate maximum stability in Purex usage. The physical properties of such a diluent should include relatively high flash polnt, low viscosity, and low density.

\section{SUMMARY}

N-dodecane was shown to be the most stable diluent among the group of normal and iso-paraffins that were tested. Its stabllity was 20 to 30 times greater than that of "Ultrasene" when exposed to $0.1 \mathrm{M}$ nitrous acid in $0.9 \mathrm{M}$ nitric acid at temperatures between 40 and $70^{\circ} \mathrm{C}$. Higher homologs in the n-parafin series were less stable than $n$-dodecane; branched paraffins were considerably less stable.

Purification of commercial n-dodecane with molecular sieves yielded a product that demonstrated excellent stabllity through the temperature range of 40 to $70^{\circ} \mathrm{C}$, and was equivalent to the high purity $\mathrm{n}$-dodecane that was used as a standard.

\section{DISCUSSION}

\section{SOURCE OF THE ZIRCONIUM LIGANDS}

An accelerated test showed that TBP did not contribute directly to the formation of ligands for zirconium and that "Ultrasene" produced much larger quantities of the ligands than pure n-dodecane. Solutions of $0.9 \mathrm{M} \mathrm{HNO}_{3}$ and $0.1 \mathrm{M} \mathrm{HNO} 2$ were prepared in each of these solvents: 100\% TBP, 30\% TBP in "Ultrasene," and 30\% TBP in n-dodecane. Samples of "Ultrasene" and n-dodecane were placed in contact with equal volumes of $4.0 \mathrm{M} \mathrm{HNO}_{3}$ containing $0.1 \mathrm{M} \mathrm{HNO}_{2}$. One aliquot of each solution and diluent sample was held at $40^{\circ} \mathrm{C}$ for 72 hours and another aliquot was held at $70^{\circ} \mathrm{C}$ for a Iike period of time. All the test materials were contained in amber, glass-stoppered bottles during degradation. After the exposure was completed, the exposed diluent samples were made up to $30 \%$ TBP 
solutions with unexposed TBP and the exposed TBP was made up to $30 \%$ solution with unexposed n-dodecane. All the solutions were then washed with dilute caustic and with water to remove alkali-soluble degradation products such as DBP and MBP. The relative amounts of zirconium Iigand formed in each of the tested solvent components and solvents were then measured by the " $Z$ " test.* The results (Table I) show that "UItrasene" was degraded more than n-dodecane or TBP by exposure to the nitric-nitrous acids and that the effect was increased in a TBP solution, probably because of the solubility of nitric and nitrous acids in the extractant.

\section{TABLE I}

Formation of Zirconium Ligands in Solvent Components and Solvents

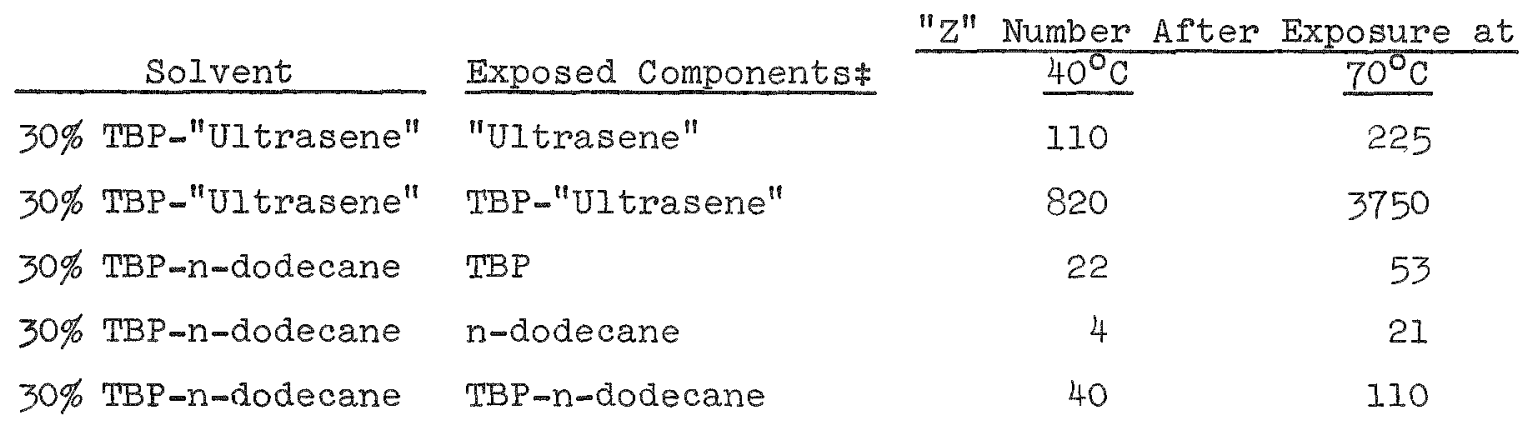

\footnotetext{
\$Exposed 72 hours at indicated temperature to mixture of nitrous and nitric acids as described in text.
}

\section{CHEMICAL STABILITY OF AVAILABLE DILUENTS}

Seven diluents were compared with "Ultrasene" with respect to chemical stability and physical properties (Table II, Page 6). A sample of $\mathrm{C}_{12}$ n-paraffin obtained from the Archer-Daniels-Midland Company was the only commercial diluent that met all the requirements satisfactorily. Branched paraffin hydrocarbons were the least stable of the compounds tested. The instability of the sample of Shell $n-C_{12}-C_{14}$, purified by the urea-occlusion process, was probably due to the incomplete removal of branched paraffins. "Amsco" 125-82 (oleum-treated naphtha) was chemically stable but had a low flash point; this material is apparently different in constitution from "Ultrasene" and "Soltrol" 170 since treatment of these diluents with oleum did not yield a significant improvement in stability.

Olefin-free n-dodecane obtained from the Humphrey-Wilkinson Company was adopted as a reference diluent. Numerous tests of this material demonstrated that it is very stable.

\footnotetext{
*In the " $Z$ " test, the solvent is washed to remove alkali-soluble components such as dibutyl phosphate, then equilibrated with a standard solution of zirconium and scrubbed with nitric acid. The residual zirconium is measured and its concentration expressed as moles per billion liters of the scrubbed solvent. (2)
} 


\section{TABLE II}

Chemical Stablilty and Phys1cal Properties of Commerc1al Diluents

\begin{tabular}{|c|c|c|c|c|c|c|c|}
\hline Diluent & Supplier & Source & $\begin{array}{l}\text { "Z" Nu } \\
\text { After } \\
\text { Expost } \\
30 \% \text { T } \\
\text { Solut } \\
40^{\circ} \mathrm{C}\end{array}$ & $\begin{array}{l}\text { mber } \\
72-h x \\
\text { re of } \\
\text { P } \\
\text { on at* } \\
\frac{70^{\circ} \mathrm{C}}{}\end{array}$ & $\begin{array}{l}\text { Flash } \\
\text { Point } \\
\text { Closed } \\
\text { Cup }{ }^{\circ}\end{array}$ & $\begin{array}{l}\text { Density } \\
D_{25}^{25}\end{array}$ & $\begin{array}{l}\text { Viscosity } \\
V_{25}^{25} \\
\text { M1111polse }\end{array}$ \\
\hline "u1trasene" & $\begin{array}{l}\text { Atlantic Refining } \\
\text { Company }\end{array}$ & Reflned kerosene & 800 & 3750 & 169 & 0.7787 & 16.2 \\
\hline "Soltrol" 170 & $\begin{array}{l}\text { Philisps } \\
\text { Petroleum Corp. }\end{array}$ & $\begin{array}{l}\text { Branched paraffin } \\
\text { mixture. Petroleum } \\
\text { by-product. }\end{array}$ & 780 & 540 & 190 & 0.7672 & 23.1 \\
\hline "Amsco" $125-82$ & $\begin{array}{l}\text { American Mineral } \\
\text { Spirits Company }\end{array}$ & Oleum-washed naphtha & 120 & 85 & 126 & 0.7480 & 12.7 \\
\hline $\begin{array}{l}\text { Atlantic propylene } \\
\text { tetramer } \\
\text { (hydrogenated) }\end{array}$ & $\begin{array}{l}\text { Atlantic Refining } \\
\text { Company }\end{array}$ & $\begin{array}{l}\text { C } 12 \text { branched } \\
\text { paraffin from hydro- } \\
\text { genated propylene } \\
\text { polymer }\end{array}$ & 5500 & 6300 & 130 & 0.7610 & 8.90 \\
\hline $\begin{array}{l}\text { Sun propylene } \\
\text { tetramer } \\
\text { (hydrogenated) }\end{array}$ & Sun 011 Company & $\begin{array}{l}\mathrm{C}_{12} \text { branched } \\
\text { parafin from hydro- } \\
\text { genated propylene } \\
\text { polymer }\end{array}$ & 180 & 1420 & 134 & 0.7535 & 11.4 \\
\hline $\begin{array}{l}\text { ShelI } C_{12}-C_{14} \\
\text { n-paraffin }\end{array}$ & Shell Oil Corp. & $\begin{array}{l}\text { n-paraffin mixture } \\
\text { from petroleum }\end{array}$ & 300 & 1360 & 181 & 0.7565 & 17.4 \\
\hline $\mathrm{C}_{14}-\mathrm{C}_{15} \mathrm{n}$-paraffin & $\begin{array}{l}\text { Archer-Daniels- } \\
\text { Midland Company }\end{array}$ & $\begin{array}{l}\text { n-parafiln mixture } \\
\text { of } \mathrm{C}_{14} \text { and } \mathrm{C}_{16} \text {. } \\
\text { Derived from } \\
\text { vegetable oils. }\end{array}$ & 110 & 250 & 245 & 0.7678 & 27.9 \\
\hline$C_{12}$ n-paraffin & $\begin{array}{l}\text { Archer-Danlels- } \\
\text { Midland Company }\end{array}$ & $\begin{array}{l}\text { n-parafiin mixture } \\
\text { containing some } C_{10} \\
\text { and } C_{14} \text {. Derived } \\
\text { from vegetable oils. }\end{array}$ & 50 & 90 & 180 & 0.7446 & 13.7 \\
\hline $\begin{array}{l}\text { Olefin-free } \\
\text { n-dodecane } \\
\text { (standard) }\end{array}$ & $\begin{array}{l}\text { Humphrey- } \\
\text { Wilkinson } \\
\text { Company }\end{array}$ & $\begin{array}{l}\text { Derived from } \\
\text { n-dodecanol }\end{array}$ & 40 & 110 & 180 & 0.7435 & 13.5 \\
\hline
\end{tabular}

* The " $Z$ " numbers of unexposed $30 \%$ TBP solutions in all diluents were between 10 and 20 . 
A method was developed for the purification of hydrocarbons which are mainly n-paraffins. The process involved the use of synthetic zeolites which are marketed as molecular sleves. The zeolite used was Molecular Sleve 13X*; it contains pores with diameters of 13 Angstroms. The pore diameter allows free passage for n-paraffins, all of which have molecular diameters of 5-6 Angstroms, while restricting the diffusion rate of branched and cyclic paraffins, which have larger molecular diameters. More polar molecules, such as olefins, appear to be held on the zeolite by adsorption.

Two different samples of Archer-Daniels-Midiand (A-D-M) $C_{12}$ n-paraffin were treated by passage through beds of Molecular Sieve 13X. The data in Table III show that the improvement in stability depends on the original stability of the dlluent. The product in both cases was as stable after treatment as the reference diluent, olefin-free n-dodecane.

\section{TABLE III}

Effect of Treatment of Commercial n-Dodecane with Molecular Sieves

\begin{tabular}{|c|c|c|c|}
\hline \multirow[b]{2}{*}{ Diluent } & \multirow[b]{2}{*}{ Sample } & \multicolumn{2}{|c|}{ " $Z$ " Number* } \\
\hline & & Original & After Treatment \\
\hline$A-D-M C_{22}$ n-paraffin & 1 & 100 & $50-60$ \\
\hline$A-D-M C_{12}$ n-parafin & 2 & 60 & $45-60$ \\
\hline olefin-free n-dodecane (control) & & 50 & $-\infty-\infty$ \\
\hline
\end{tabular}

\$Exposed as a $30 \% \mathrm{TBP}$ solution at $70^{\circ} \mathrm{C}$ for 72 hours in the presence of $0.9 \mathrm{M} \mathrm{HNO}_{3}$ and $0.1 \mathrm{M} \mathrm{HNO}_{2}$

*obtalned from Linde Air Products Company

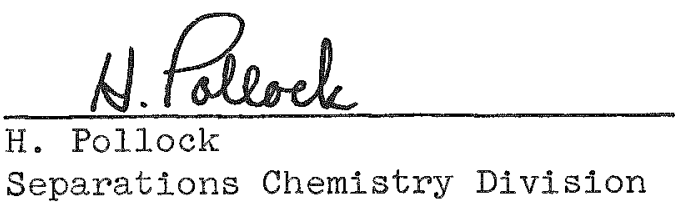

\section{BIBLIOGRAPHY}

I. Siddall, T. H., III, and Wallace, R. M. E. I. du Pont de Nemours and Co., DP-286, May 1958 (Confidential).

2. Garrett, T. P., Jr. A Test for Solvent Quality. E. I. du Pont de Nemours and Co., DP-237, August 1957. 